\title{
Deforestation in Conservation Units of the Brazilian Amazon: the case of the Terra do Meio Mosaic
}

\author{
Silvia Cristina de Jesus I; Adriana Maria Zalla Catojo II
}

\begin{abstract}
The Terra do Meio Mosaic in the Brazilian Amazon was created with the purpose of inhibiting illegal logging and gold mining, as well as land grabbing, cattle raising and other activities that promote deforestation in the region. This work analyzes the dynamics of the deforestation (clear-cutting) in this set of Conservation Units and how they contain deforestation in the region. These protected areas have been shown as an efficient tool in conserving natural ecosystems, with maintenance of main forest cover. The exception is the Triunfo do Xingu Environmental Protection Area which has less power to contain deforestation because it is a category that involves private lands. Na important reason for the clear cut of the forest is the establishment of pasture for cattle breeding. In the municipalities that contains the Mosaic, the small properties (up to 4 fiscal modules) are the ones that present the highest proportion of deforestation. The Indigenous Lands also play an important role in the maintenance of the Conservation Units functioning as a protective boundary zone and in refraining the clear-cutting, which occurs mainly in the surroundings of rivers and roads.
\end{abstract}

Keywords: Conservation Units; Protected Areas; Deforestation; Brazilian Amazon; Terra do Meio Mosaic 


\section{INTRODUCTION}

Besides the importance of the socio-biodiversity for conservation, the protected areas in the Brazilian Amazon are inestimable for concentrating great amounts of carbon. Thus, safeguarding the protection of these areas reduces the risk of future carbon emissions associated to land use changes that cause impacts in the composition of the terrestrial atmosphere and in the climate, by means of biogeochemical and biogeophysical processes, with alterations in albedo, evapotranspiration and superficial roughness. The conversion of forests to simpler systems also leads the great emissions of carbon dioxide in the atmosphere that, as effect greenhouse gas, modifies the Earth's energy balance and the climate (BONAN, 2008; NOGUEIRA et al., 2018).

The reduction of tropical forests represents one of the main current environmental issues, being the establishment of Conservation Units (CUs) the main resource to contain the degradation and deforestation in the Brazilian Amazon, especially at the agricultural frontiers (FEARNSIDE, 2017, NEPSTAD et al., 2006).

The understanding that protected areas hinder the socioeconomic development is still common and threaten the management of protected areas (PAs) (BRITO et al., 2014). However, Strand et al. (2018) showed the value of forest ecosystem services in Brazil nut production, rubber and wood supply, carbon uptake and storage, and climate regulation. The authors concluded that deforestation impairs the production of Brazil nuts and sustainable timber and that the sum of the forest's environmental services may be higher than that received by low productivity livestock in some areas. These results coincide with those obtained by Young and Medeiros (2018) who showed that the economic and social return is much higher than the amounts invested in the management of protected areas, and most of the benefits promoted by the CUs reach regions far from the large urban centers. This is because natural resources can be extracted sustainably in the CUs that allow mercantile activities, especially non-timber forest products, which have great value in the extractive peoples' family income. In addition, the implementation and conservation of CUs prevent carbon emissions, contribute to the protection of water resources and erosion control and results in the transfer of the tax amount (Ecological - Goods and Services Tax).

This work analyzes the occurrence of the deforestation (clear-cutting) in the Terra do Meio Mosaic and where the deforestation is most intense, differentiating forest suppression between full protection and sustainable use. 


\section{STUDY AREA}

The Terra do Meio Mosaic is constituted by the Triunfo do Xingu EPA, Rio Xingu ER, Rio Iriri ER, Riozinho do Anfrísio ER, Verde para Sempre ER, Trairão NF, Altamira NF and Iriri SF (USUCS) and Terra do Meio ES, Jamanxim NP and Serra do Pardo NP (Full Protection Conservation Units), totalizing 105,395 km2 (Figure 1). The set of CUs covers the municipalities of Altamira, São Félix do Xingu, Itaituba, Porto de Moz, Trairão and Rurópolis, all in the Pará State.

Figure 1 - Location of the Terra do Meio Mosaic

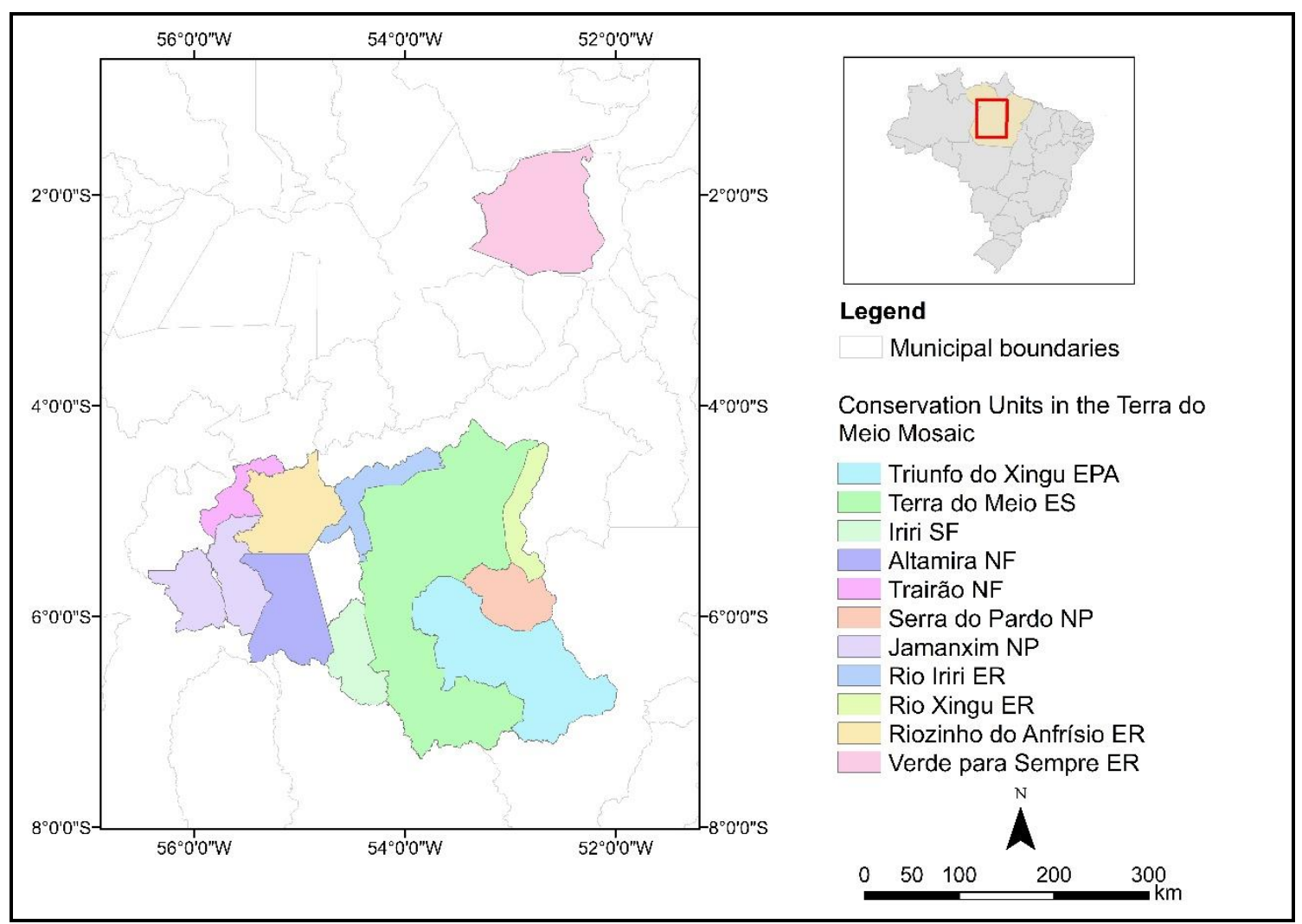

The establishment of the Terra do Meio Mosaic was one of the achievements of the Action Plan for Prevention and Control of the Legal Amazon Deforestation (PPCDAm = Plano de Ação para Prevenção e Controle do Desmatamento na Amazônia Legal ) in the years 2004 and 2005 (MMA, 2018). The Plan was created in 2004 and considered agrarian and territorial order as main objectives, including the creation of Conservation Units in the Terra do Meio region. In the first phase of PPCDAm more than 25 million hectares of Federal CUs were created in the Brazilian Amazon, comprising the Conservation Units of 
the Terra do Meio Mosaic with exception of Altamira National Forest, created in 1998 (Table 1).

Table 1 - Conservation Units of the Terra do Meio Mosaic

\begin{tabular}{|c|c|c|c|c|c|}
\hline Use & Name & $\begin{array}{c}\text { Area } \\
\left(\mathbf{k m}^{2}\right)\end{array}$ & $\begin{array}{l}\text { Year of } \\
\text { creation }\end{array}$ & $\begin{array}{l}\text { Managem } \\
\text { ent Plan }\end{array}$ & $\begin{array}{c}\text { Administrative } \\
\text { supervision }\end{array}$ \\
\hline \multirow{6}{*}{$\begin{array}{l}\text { Full } \\
\text { Protection }\end{array}$} & Serra do Pardo NP & 4,458 & 2005 & No & Federal \\
\hline & Terra do Meio ES & 33,701 & 2005 & Yes & Federal \\
\hline & Jamanxim NP & 8,624 & 2006 & No & Federal \\
\hline & Iriri SF & 4,393 & 2006 & No & State \\
\hline & Triunfo do Xingu EPA & 16,822 & 2006 & No & State \\
\hline & Altamira NF & 7,596 & 1998 & Yes & Federal \\
\hline Sustainable & $\begin{array}{c}\text { Verde para Sempre } \\
\text { ER }\end{array}$ & 12,844 & 2004 & No & Federal \\
\hline \multirow[t]{4}{*}{ Use } & $\begin{array}{c}\text { ER Riozinho do } \\
\text { Anfrísio }\end{array}$ & 7,365 & 2004 & Yes & Federal \\
\hline & Trairão NF & 2,569 & 2006 & Yes & Federal \\
\hline & Rio Iriri ER & 3,962 & 2006 & Yes & Federal \\
\hline & Rio Xingu ER & 3,062 & 2008 & Yes & Federal \\
\hline
\end{tabular}

$\mathrm{NP}=$ National Park; ES = Ecological Station; SF = State Forest; EPA = Environmental Protection Area; NF = National Forest; ER= Extractive Reserve.

At the beginning of the 1970's decade, during the military dictatorship in Brazil, the government encouraged the migration of populations from the Northeast and South of the country to colonize the West of Pará State with the promise of land and money. During this period, when the opening of Transamazonica Highway (BR-230) began, the deforestation in the region was intensified, initially with the degradation of the forests for logging and then with the conversion of these areas into pastures for cattle raising. However, after fifty years, the agreement was not fulfilled and the migrants, or settlers, began to live a life of deprivations while becoming hostages of the contemporary slave labor. In the 1990's, the dispute over land and forest natural resources started an intensive process of illegal land grabbing, frauds and illegal logging and the establishment of mining. The riverine people were then banished from their lands or received death 
threats. Logging, livestock, agriculture, fishing, extractivism and industrial mining have been the main activities in the Terra do Meio region, characterized by conflicts between riverine people, settlers, loggers and land grabbers (ANDERSEN et al., 2002; FEARNSIDE, 2005; FEARNSIDE, 2008; OLIVEIRA, 2008).

Villas-Bôas et al. (2003) indicates that the preliminary studies for the creation of a mosaic of protected areas suggested the presence of a population of 739 individuals who lived in the Terra do Meio region, of which 350 inhabited the Iriri River. In the beginning, the decision of which categories would be attributed to the Conservation Units of Terra do Meio had considered these demographic data, and the initial proposal of the set of CUs would contemplate the implementation of Sustainable Use Conservation Units (SUCUs). However, the planned limits were changed and an extension of land was destined for the Terra do Meio ES, a category incompatible with human occupation, triggering an agrarian conflict (ALARCON and TORRES, 2014). The conditions for the permanence of traditional populations within CUs must be in agreements signed between the occupants and the environmental agency. The Federal Constitution (BRAZIL, 1988) and the Convention 169 of the International Labor Organization (BRAZIL, 2004) guarantee the right of these families to stay in protected areas.

\section{METHODS}

The methodology involved the compilation, organization and processing of Conservation Units geospatial data (Table 2).

\subsection{Land cover map 2017}

The land cover map for 2017 was acquired from the MapBiomas tools - Collection 3 - available on the Google Earth Engine platform (https://code.earthengine.google.com/?accept_repo=users/mapbiomas/user-toolkit). These are annual land cover maps generated from images from the Landsat collection, with an overall accuracy of over $82 \%$ (MAPBIOMAS, 2018).

\subsection{Deforestation data}

The deforestation data was acquired on PRODES platform (http://www.dpi.inpe.br/prodesdigital/prodes.php). It relates to polygons generated from 
the visual interpretation of Landsat images with 30 meters of spatial resolution, being identified the areas with complete removal of primary forest cover by clear-cutting with minimum mapped area of 6.25 hectares (INPE, 2018a). Data was analyzed from 2008, since deforested areas up to this point are considered as consolidated by the Law of Protection of Native Vegetation (BRAZIL, 2012).

\subsection{Fire occurrence}

The fire points during the period from 2008 to 2017 in the area of interest were acquired in the platform of the monitoring system BDQueimadas, being considered the data of the reference satellite (AQUA EOS PM) (INPE, 2018b).

\subsection{Conservation Units and other protected areas boundaries}

The limits of the State and Federal Conservation Units in shapefile format were made available by the Socioenvironmental Institute (ISA = Instituto Sociambiental); the data on Indigenous Land (ILs) and Maroon Territories ("Quilombos") are available on the homepages of the National Indian Foundation (FUNAI = Fundação Nacional do Índio) and National Institute for Colonization and Agrarian Reform (INCRA = Instituto Nacional de Colonização e Reforma Agrária).

\subsection{Limits of the properties registered in SICAR}

The properties registered in SICAR until February $27^{\text {th }}, 2019$ and located in the municipalities that contains the Terra do Meio Mosaic (Altamira, São Félix do Xingu, Itaituba, Porto de Moz, Trairão and Rurópolis) were analyzed (SICAR, 2018). For all these municipalities, the fiscal module is equivalent to 75 hectares (INCRA, 2019).

\subsection{Mining processes}

The mining processes registered in the National Department of Mineral Production $\left(\right.$ DNPM $=$ Departamento Nacional de Produção Mineral) until December 08 $8^{\text {th }}, 2018$ that are inside or are adjacent to the Terra do Meio Mosaic are quantified (ANM, 2018).

For the calculation of the area was considered the South America Albers Equal Area Conic projection.

Kernel density map for the centroids of the deforestation polygons (INPE, 2018a) was generated for the area of the Landsat path/rows which covered the study area using ArcGIS 10.5 . 
Table 2 - Spatial data used for analyzing deforestation in the Terra do Meio Mosaic

\begin{tabular}{lcc}
\hline Data & Reference date & Source \\
\hline Land cover map & 2017 & MapBiomas, 2018 \\
Deforestation polygons & from 2008 to 2017 & INPE, 2018a \\
Fire points & from 2010 to 2017 & INPE, 2018b \\
Conservation Units boundaries & updated in 2018 & ISA, 2018 \\
Limits of properties of properties registered in the & updated in 2019 & SICAR, 2019 \\
National System of Rural Environmental Register & & \\
\hline
\end{tabular}

\section{RESULTS AND DISCUSSIONS}

The Serra do Pardo NP, Jamanxim NP, Iriri SF, Triunfo do Xingu EPA and Verde para Sempre ER do not have their Management Plans. This means that $45 \%$ of the area of the CUs set is managed without this legal instrument.

The dominant land cover in the Mosaic of Conservation Units of Terra do Meio is the native forest formation, with almost $100 \%$ even in sustainable use units. Triunfo do Xingu EPA presents approximately $20 \%$ of land destined for agropastoral activities, but still has significant native forest cover (Figure 2). The Triunfo do Xingu EPA has a lower proportion of native forest formation than other SUCUs because it is a less restrictive land use category that allows private properties (Figure 3). The forest proportion in FPCUs is lower than the SUCUs since Terra do Meio ES and Serra do Pardo NP have areas of other non-forest natural formations.

Figure 2 - Land cover in the Terra do Meio Mosaic CUs (MAPBIOMAS, 2018)

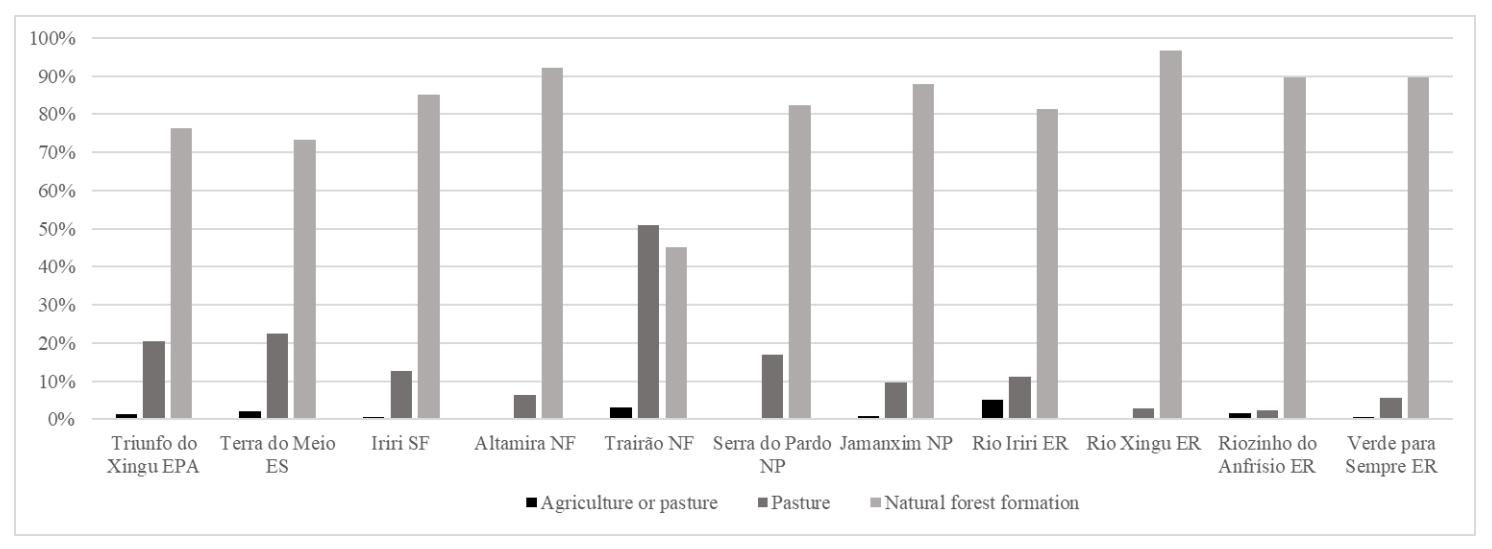


Figure 3 - Land cover in the Terra do Meio Mosaic analyzed by the use of the CUs (MAPBIOMAS, 2018)

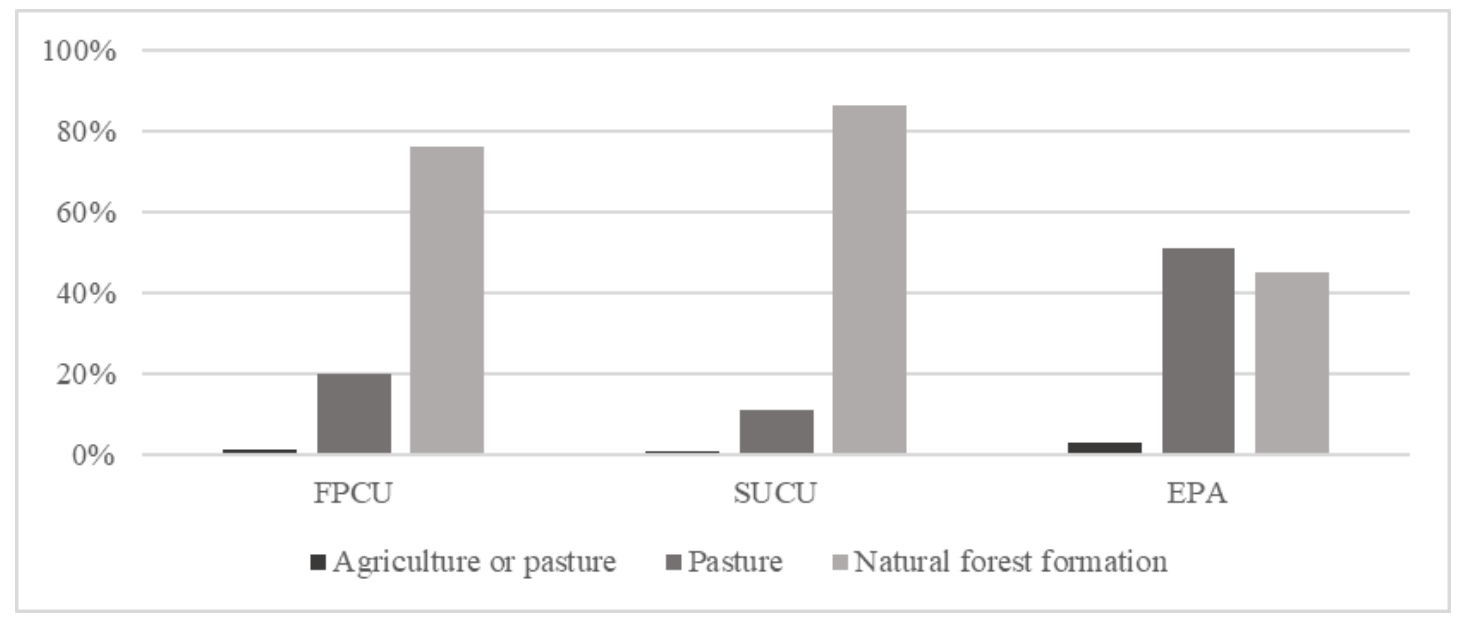

The lowest rates of deforestation in the entire Brazilian Legal Amazon occurred in the third phase of the PPCDAm since 2009, when there was a $42 \%$ reduction in the deforested area (INPE, 2018a); but in 2016, at the beginning of the fourth phase of this Plan (2016-2020) there was a $29 \%$ increase in deforestation in relation to the previous year (when deforestations were growing again). The Pará State as a whole also followed this multitemporal pattern (INPE, 2018a) as did the Triunfo do Xingu EPA and Altamira NF (Figure 4). It is in these CUs that accumulated deforestation since 1998 is larger, representing $32 \%$ and $8 \%$, respectively (Figure 5 ).

Figure 4 - Annual percentage of deforestation in the Mosaic of Terra do Meio (INPE, 2018a)

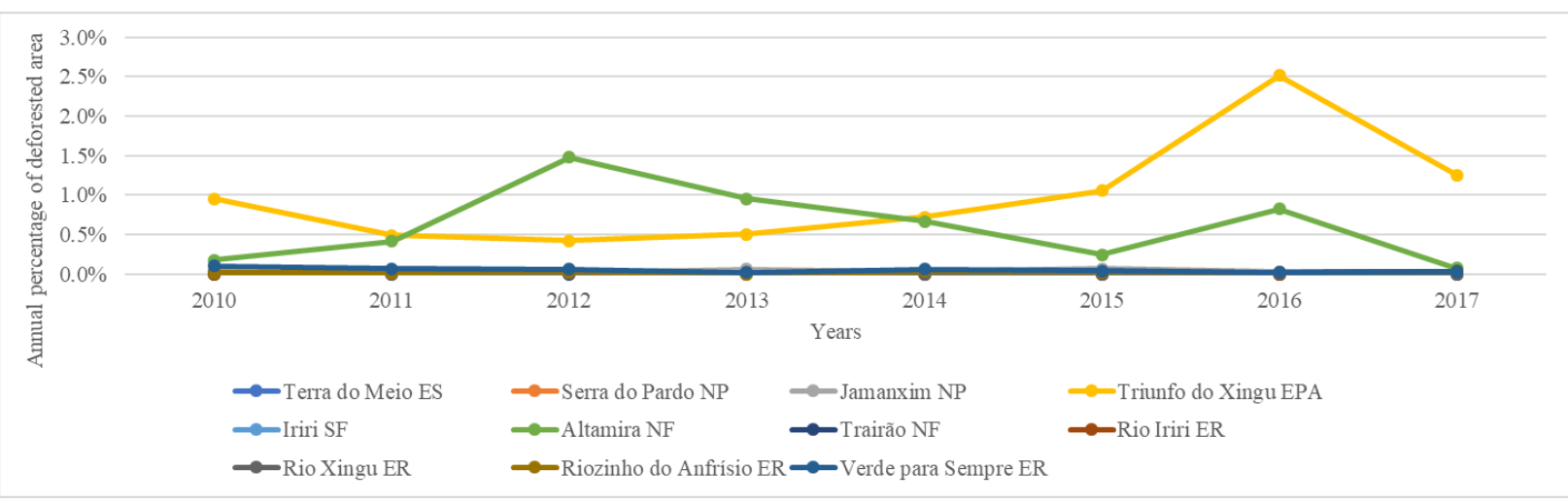


Figure 5 - Cumulative percentage of deforestation since 1998 in the Terra do Meio Mosaic CUs (INPE, 2018a)

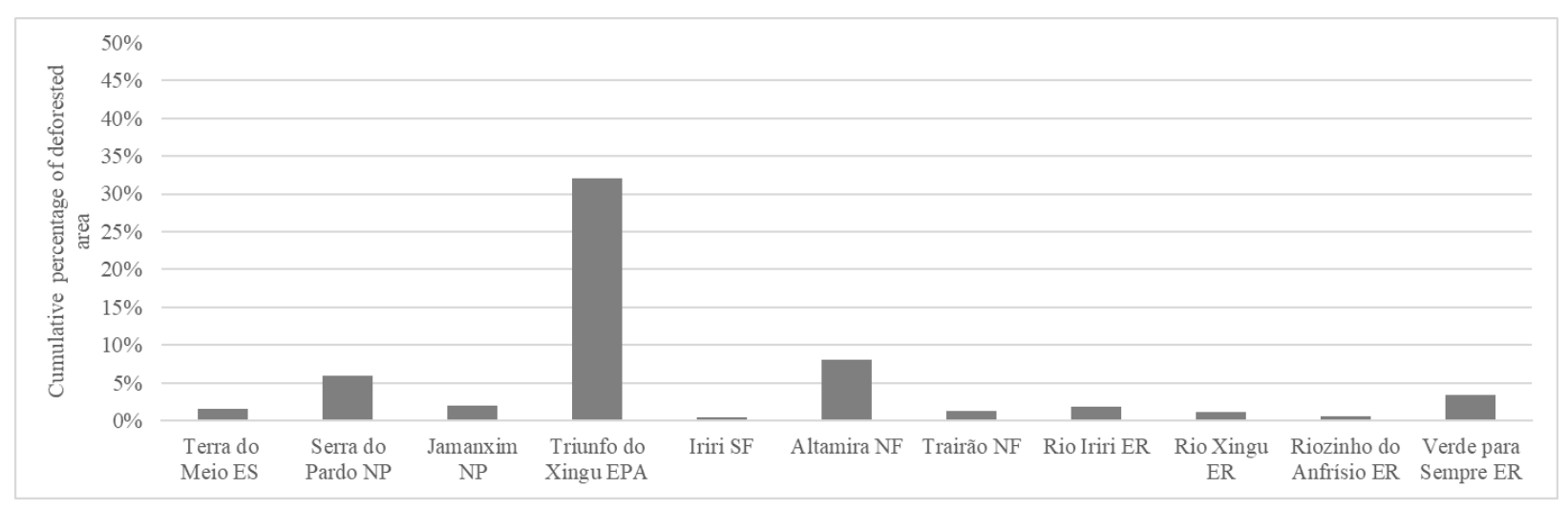

On the other hand, The Jamanxim NP presents only $2 \%$ of its deforested area but suffers great pressure from the BR-163 (Cuiabá-Santarém highway), that crosses the park, with areas strongly anthropized in its surroundings. In addition, the perimeter of this $\mathrm{CU}$ was delimited considering a deviation to not comprise the area deforested prior to its creation (Figure 6a). According to SNUC (BRAZIL, 2000), only indirect use of natural resources is allowed in this $\mathrm{CU}$ category, what stands against the occurrence of the forest clear cut for logging and ranching.

The Serra do Pardo NP is the FPCU with the highest accumulated deforestation since 1998. This CU presents anthropized areas from its limit with the Triunfo do Xingu EPA and which enter the Park; there are private properties registered inside this unit totalizing 53,395 hectares (12\% of the Park area), which is not compatible with that category (Figure $6 \mathrm{~b}$ ).

The Extractive Reserves, the Iriri SF and the Trairão NF have accumulated deforestation of less than $4 \%$ of their extensions. Rasker and Hansen (2000) point out that protected areas surrounded by human communities that benefit from them may be less susceptible to degradation due to a greater probability of management on a regional scale and in accordance with the objectives of these CU categories.

The most anthropized portion of the Triunfo do Xingu EPA is in the municipality of São Félix do Xingu, whose urban network is on the other bank of the Xingu River, one of the boundaries of the CU. The Serra do Pardo NP and the Terra do Meio ES, both FPCUs, adjacent to the Triunfo do Xingu EPA, suffer the anthropogenic pressures in the EPA with deforestation sites at the boundaries between the units. The Triunfo do Xingu EPA was established in an area that, at the time of its creation, in 2006, already had more than 12,100 ha $(13 \%)$ of anthropized area, occupied by agropastoral activities (MapBiomas, 2018). 
Figure 6 - Cumulative deforestation in surroundings of (a) Jamanxim NP; (b) Serra do Pardo NP

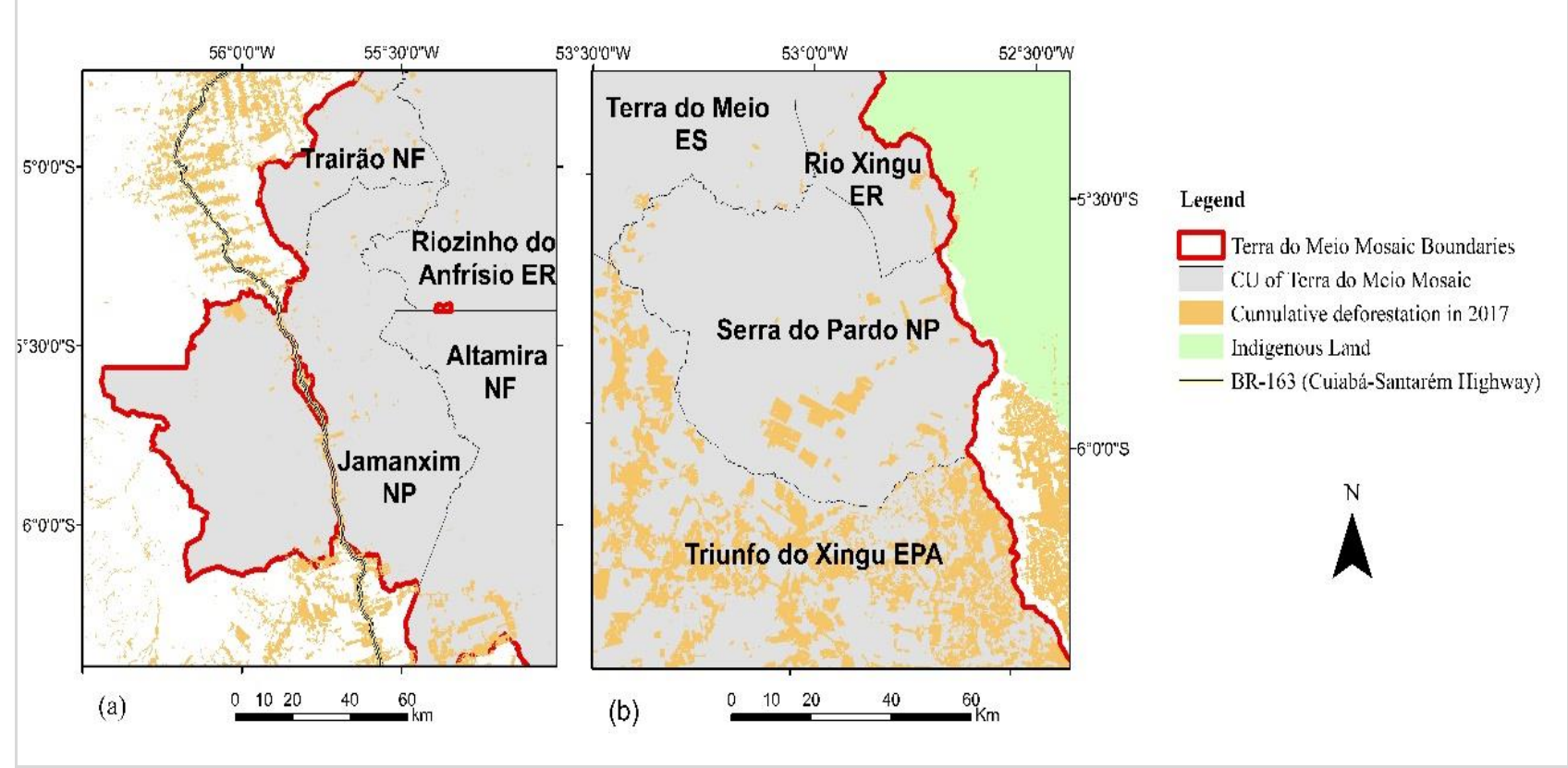

Figure 7 shows that the large deforestation occurs in unprotected areas, outside Conservation Units (CUs) and Indigenous Lands (ILs). In general, the CUs and ILs contain deforestation in the Amazon, with exception of the Triunfo do Xingu EPA that suffers a hard anthropogenic pressure in the portion located in the municipality of São Félix do Xingu. Outside protected areas, deforestation areas occur mainly in the vicinity of rivers and highways. Figure 8 shows vast areas of clear cut in the vicinity of Tapajós and Amazon Rivers and BR-163 and BR-230 highways. This analysis is consistent with the results of Barber et al. (2014) who concluded that $95 \%$ of all deforestation in the Brazilian Amazon occurred within $5.5 \mathrm{~km}$ of roads or $1 \mathrm{~km}$ of rivers, and there are differences whether it is protected areas (10.9\% deforestation) or unprotected ( $43.6 \%$ deforestation). However, in the case of the Terra do Meio Mosaic, the Terra do Meio Ecological Station, a Full Protection Conservation Unit, is under pressure from BR-230. 
Figure 7 - Deforestation in protected areas around the Terra do Meio Mosaic

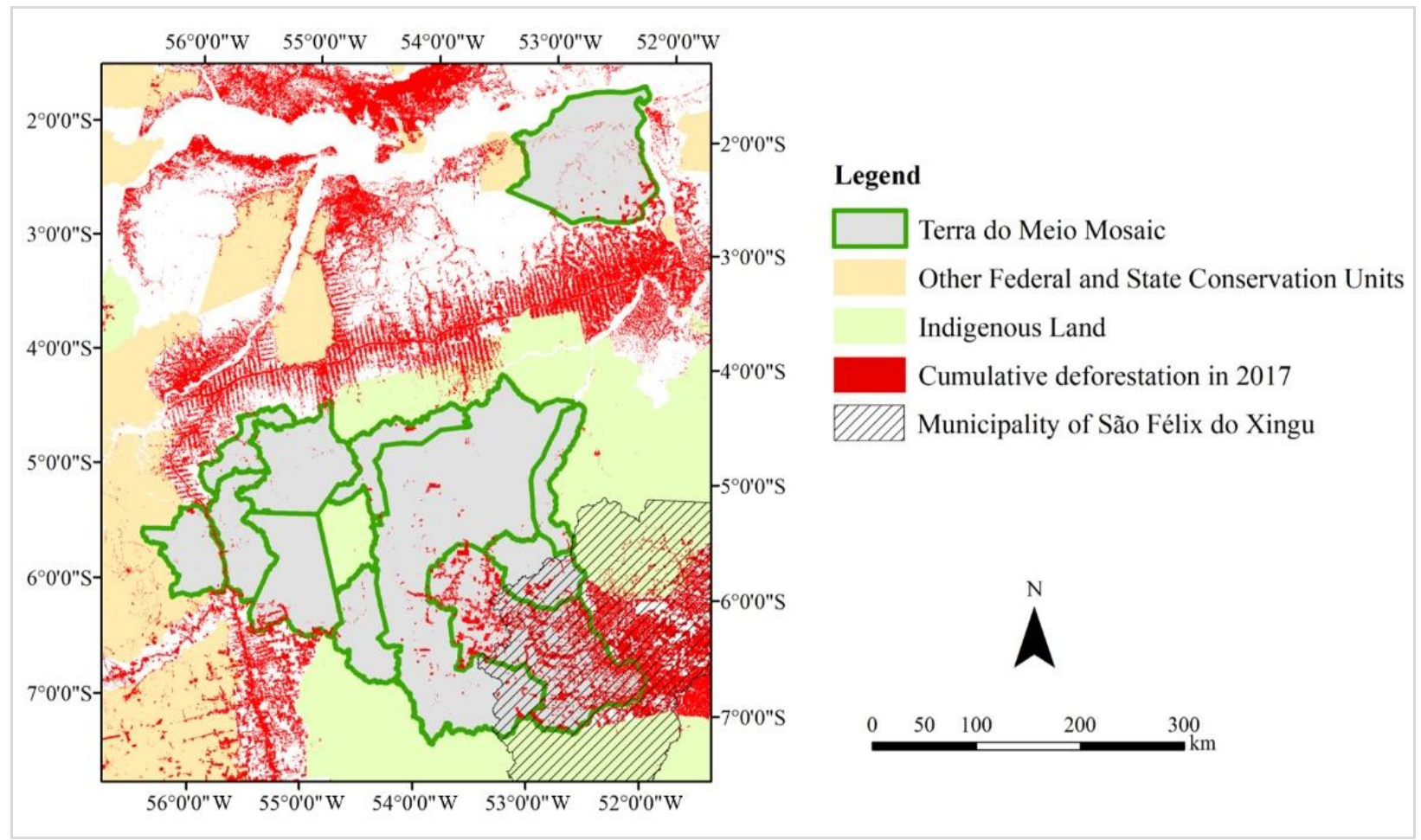

Figure 8 - Location of the deforested areas in relation to the main rivers and highways in the vicinity of the Terra do Meio Mosaic

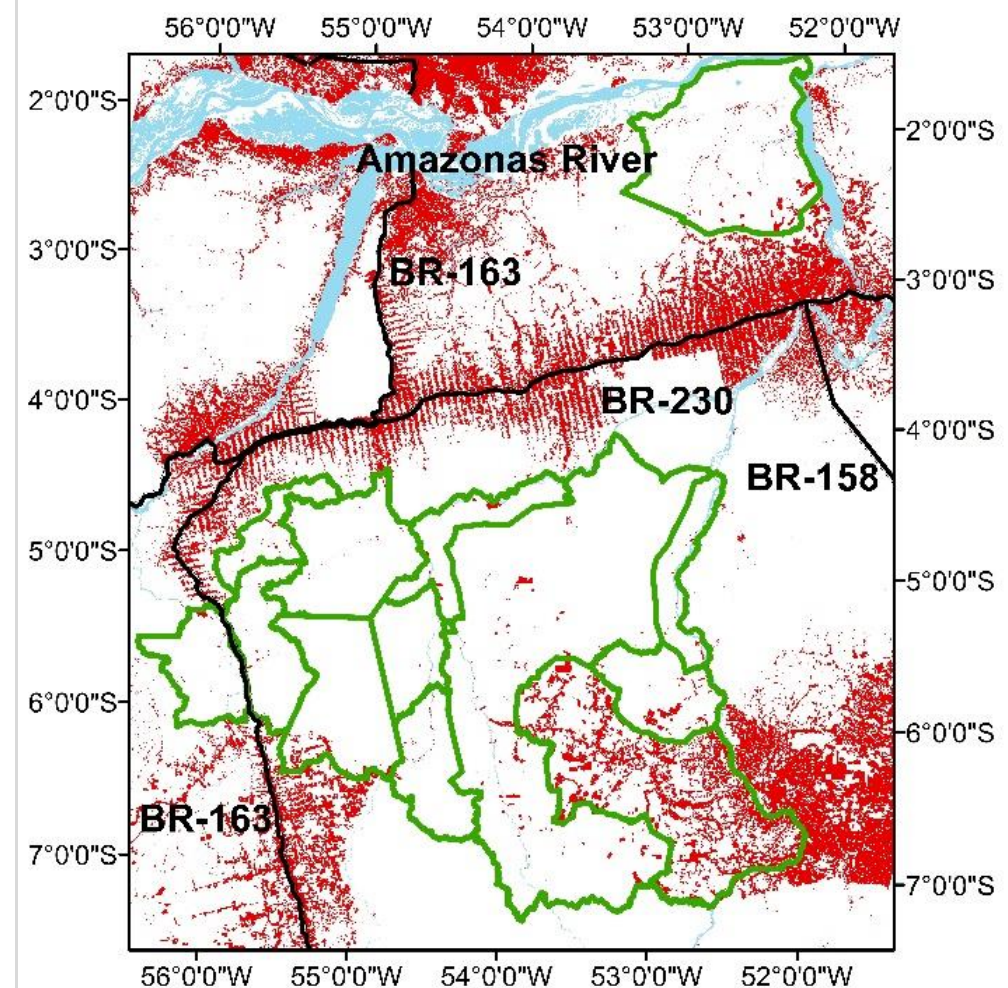

\section{Legend}

$\square$ Terra do Meio Mosaic

Cumulative deforestation in 2017 Hydrography Highways under direction of the

- National Department of Transport Infrastructure

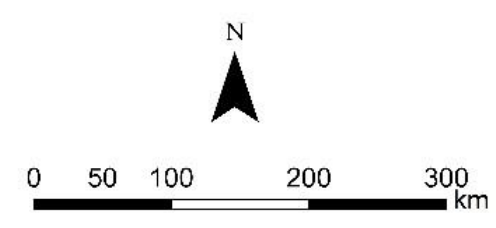


The Kernel density map (Figure 9) confirms that the surroundings of the Triunfo do Xingu EPA, of BR-230 and the surroundings of the Amazon River and the BR-163 are the sites where the largest deforestation polygons are concentrated, considering all the PRODES history (INPE, 2018a).

Figure 9 - Kernel density map showing the concentration of major deforestation polygons

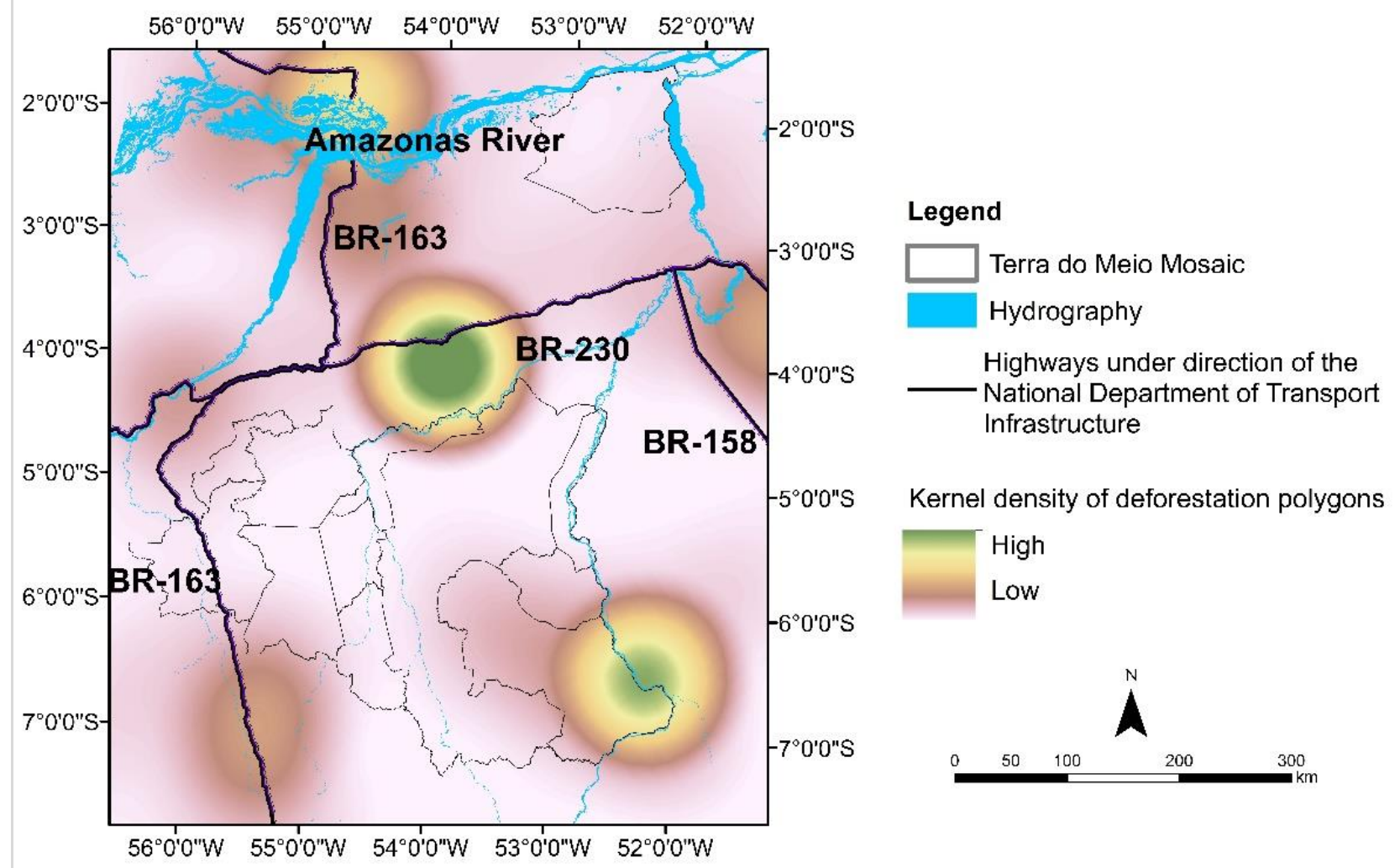

The anthropization pressure in the surroundings of the Terra do Meio Mosaic is mainly a consequence of the extensive cattle raising in the Pará State. Figure 10 shows the evolution of livestock in the State of Pará. In 2017, the municipality of São Félix do Xingu was the first in the Brazilian ranking of bovine cattle with more than 2.2 million heads of cattle, or $1 \%$ of the national total (IBGE, 2018). Verburg et al. (2014) explains that the already degraded areas, if properly managed through techniques of soil recovery and intensification, could be destined to the development of the agricultural sector, which means that deforestation for the opening of new areas is unnecessary. Furthermore, the expansion of agroforestry activities in the Amazon can lead to declines in agricultural productivity, which may increase below what would be proportional to agricultural 
expansion or even decrease due to the reduction in precipitation caused by changes in land cover (Oliveira et al., 2013).

Figure 10 - Evolution of livestock in the state of Pará (IBGE, 2018)

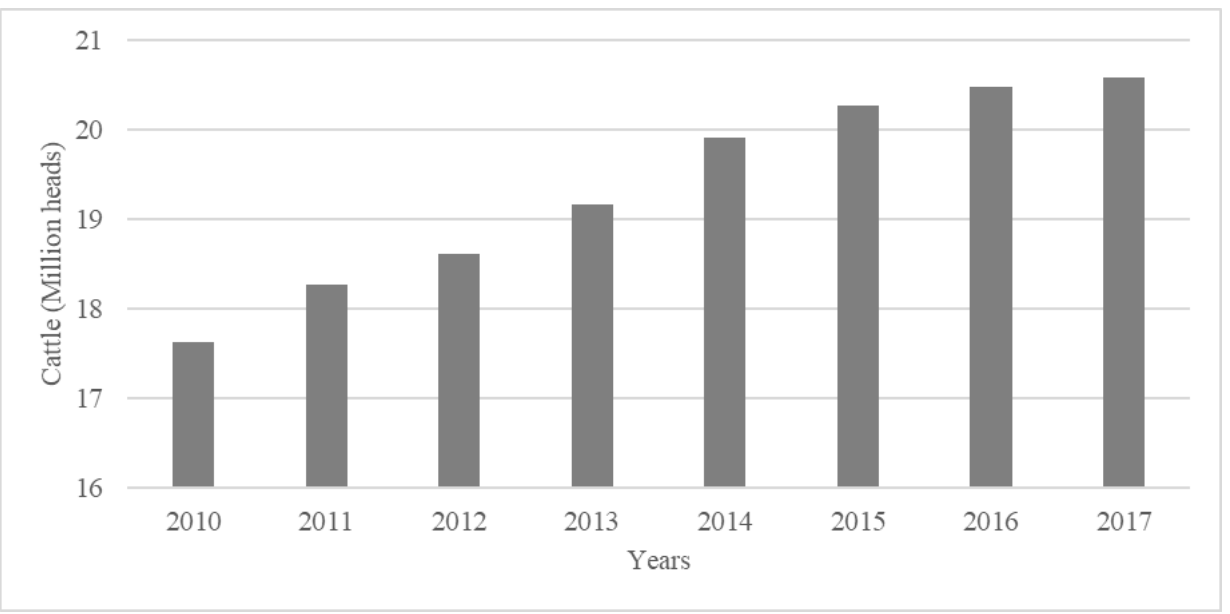

The existence of private properties and economic activities within the FPCUs is one of the main challenges for the management of these areas, and land regularization is a priority for the management councils and competent agencies. Once the Conservation Unit is created, any economic activities within its boundaries and in its buffer zone (BZ) require environmental licensing, which will not be authorized for these areas (FARENA, 2007). The Internal Zoning of the Terra do Meio ES shows that there are allotments in expropriation phase, located in the Temporary, Recovery and Primitive Zones, and also in the neighborhoods of the Triunfo do Xingu EPA limit (ICMBIO, 2015).

In the 1990s, Fearnside (1993) estimated that $70 \%$ of deforestation in the Legal Amazon occurred in the medium and large properties (greater than 100 hectares), witch occupied $89 \%$ of the private land, but that the intensity of deforestation (ha/year $/ \mathrm{km}^{2}$ of private land) is greater on properties with up to 100 hectares. However, that it is in the small properties (with up to 2 fiscal modules) of the municipalities that the deforested area predominates; the proportion of forested areas tends to increase with the size of the properties. Figure 11 shows the average percentages of deforested area (pasture, agriculture and mining) and native forest area (MAPBIOMAS, 2018) in rural properties (SICAR, 2019) in Altamira, São Félix do Xingu, Itaituba, Porto de Moz, Trairão and Rurópolis in 2017. 
Figure 11 - Average percentages of deforested area (pasture, agriculture and mining) and native forest area (MAPBIOMAS, 2018) in rural properties (SICAR, 2019) in municipalities where the Terra do Meio Mosaic conservation units are located

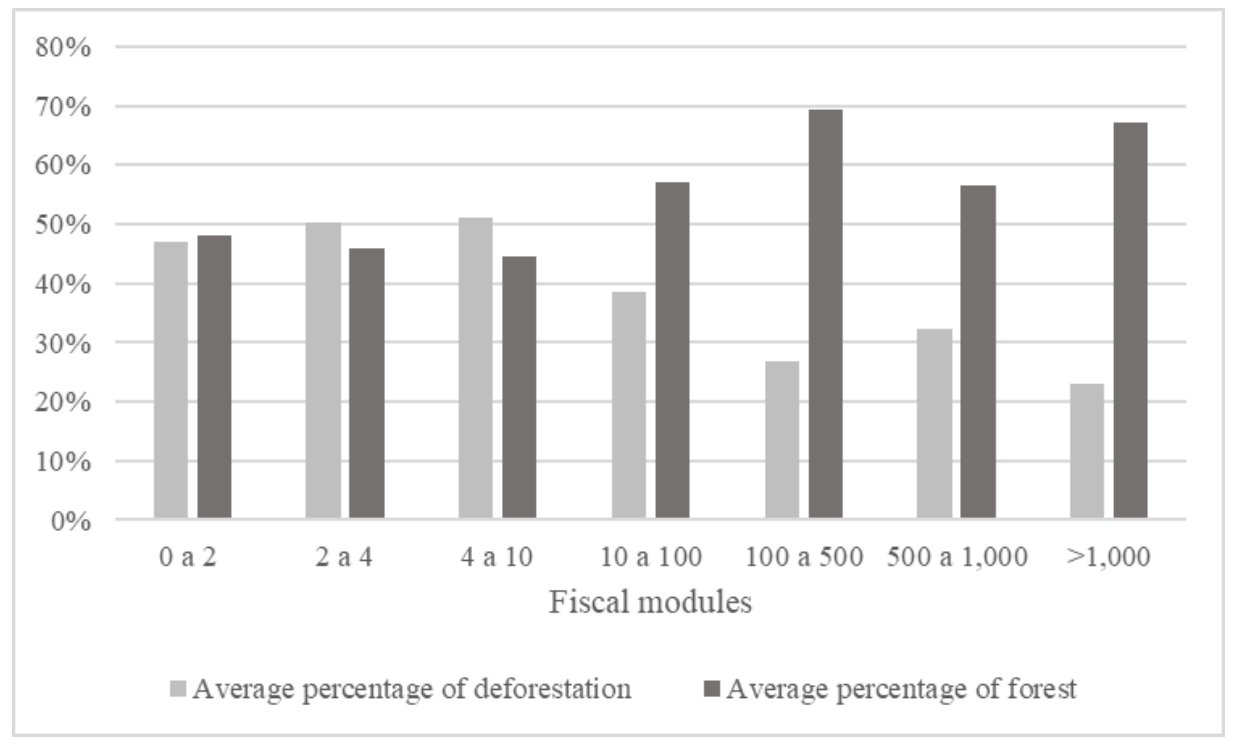

The Native Vegetation Protection Law (NVPL), popularly named as New Brazilian Forest Code (Law no 12,651, of the May 25th, 2012) redefines the size of the bands of Permanent Preservation Areas, exempts the recomposition of the respective marginal bands in areas which are already consolidated in private properties and amnestied fines and other sanctions for those who deforested before July 22nd, 2008. This Law favors deforestation in properties with up to two fiscal modules.

This information is consistent with the observations of Braga and Martensen (2017) who concluded that the Brazilian environmental legislation legitimizes the deforestation for the small agriculturists and allows the acquisition of small continuous properties for the great proprietors. That is, when the joining of several small properties forms a large property, the less restrictive rules applied to small properties are passed on to the new landowner. The same situation favors the loggers, who can withdraw a greater contribution of wood per unit of the property in smaller properties. This loosening of the law on smallholdings, which means consent to deforestation, affects adjacent protected areas where private property is not allowed. More than ten years after the creation of the most recent CU in the mosaic, there are still lands in expropriation phase that were declared in the Rural Environmental Registry.

The NVPL also provides for the Legal Reserves which is an area of native vegetation that must be maintained in all rural properties, with a minimum percentage of $80 \%$ in 
properties situated in forested areas. The suppression of native vegetation in these areas, as well as in the areas of permanent preservation can damage the continuity of environmental services such as water purification, soil protection, pollination of crops and regulation of the microclimate, which are also important factors for the maintenance of agricultural activities developed on rural properties (Brancalion et al., 2016)

Setzer et al. (2013) found that the monitoring of fires allows the identification and the prediction of trends of illegal deforestation in advance. Figure 12 shows the density of fire points (fire points $/ \mathrm{km} 2$ ) detected by the satellite AQUA EOS PM in the Terra do Meio Mosaic. The occurrence of fires in the Triunfo do Xingu EPA is significantly higher than in the other CUs of the set, with more frequent episodes in the years 2010, 2015 and 2017. Looking at the use of CU (FPCU, SUCU and EPA), it can be seen that the annual density of fires is up to 0.01 fires $/ \mathrm{km} 2$ in units where land use is more restricted whereas in EPAS the density of fires was always higher than in other units over years (Figure 13). Although Jamanxim NP and Altamira NF maintain low fire densities over the years, these units come under pressure from outside, from unprotected areas or other non-mosaic CUs like the Tapajós EPA.

Figure 12 - Fire points density in the Terra do Meio Mosaic (INPE, 2018b)

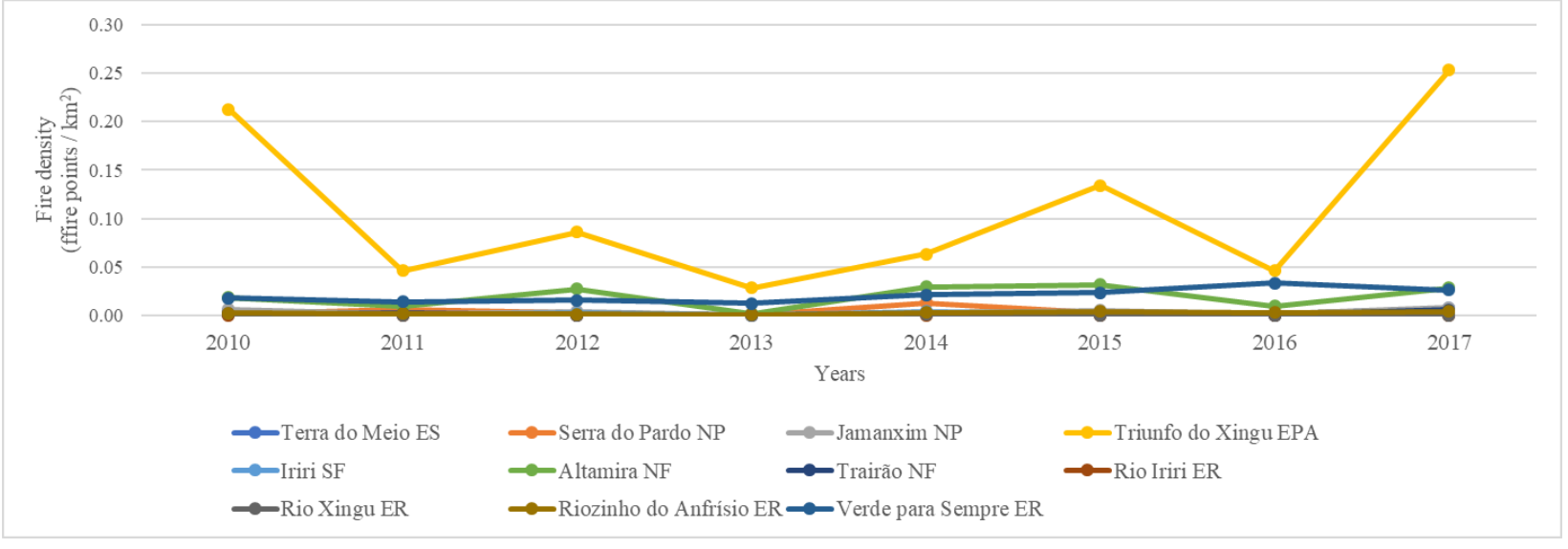

The anomaly map (Figure 14) shows the deviation in relation to the monthly average rainfall volume in the Terra do Meio Mosaic; it is assumed that the variation of \pm $25 \mathrm{~mm}$ is within the mean, with blue tones indicating above-average rainfall and yellow and red tones indicating below-average rainfall. August has the highest average incidence of fires (Figure 15); for the mentioned years, the precipitation in the Triunfo do Xingu EPA was just below average (-25 $\mathrm{mm}$ to $25 \mathrm{~mm}$ ). Thus, the increase in the number of fire points had no climatic reasons. 
Figure 13 - Fire points density in the Terra do Meio Mosaic analyzed by the use of the CUs (INPE, 2018b)

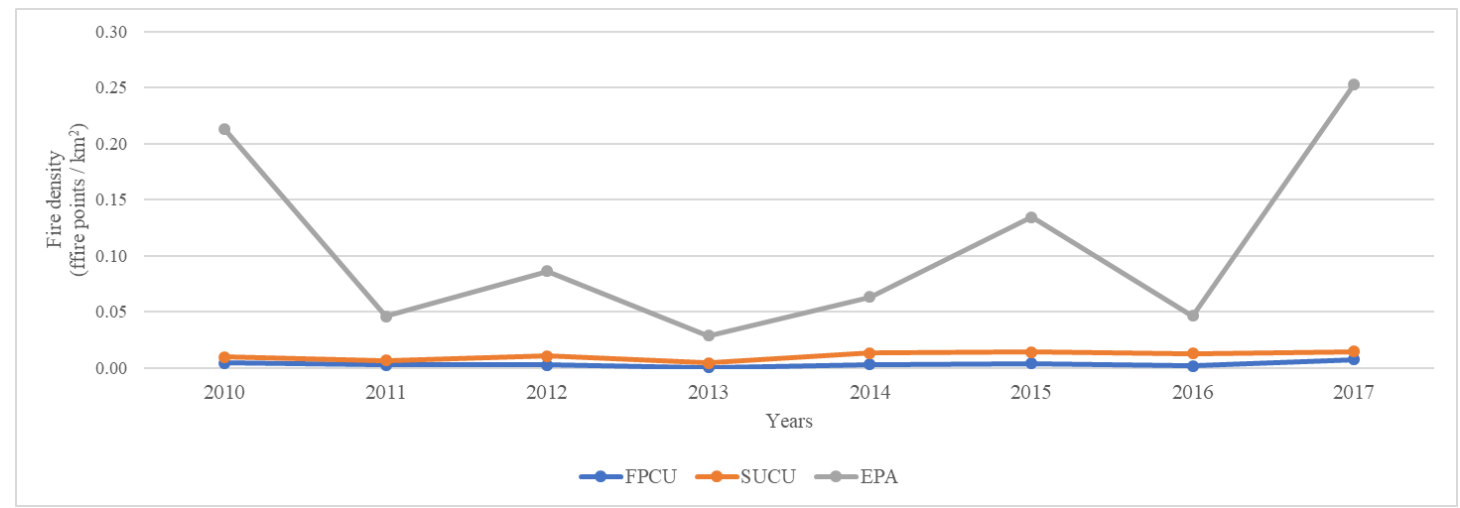

Figure 14 - Precipitation anomaly (mm) in the month of August of the years 2010, 2015 e 2017 (CPTEC, 2018)

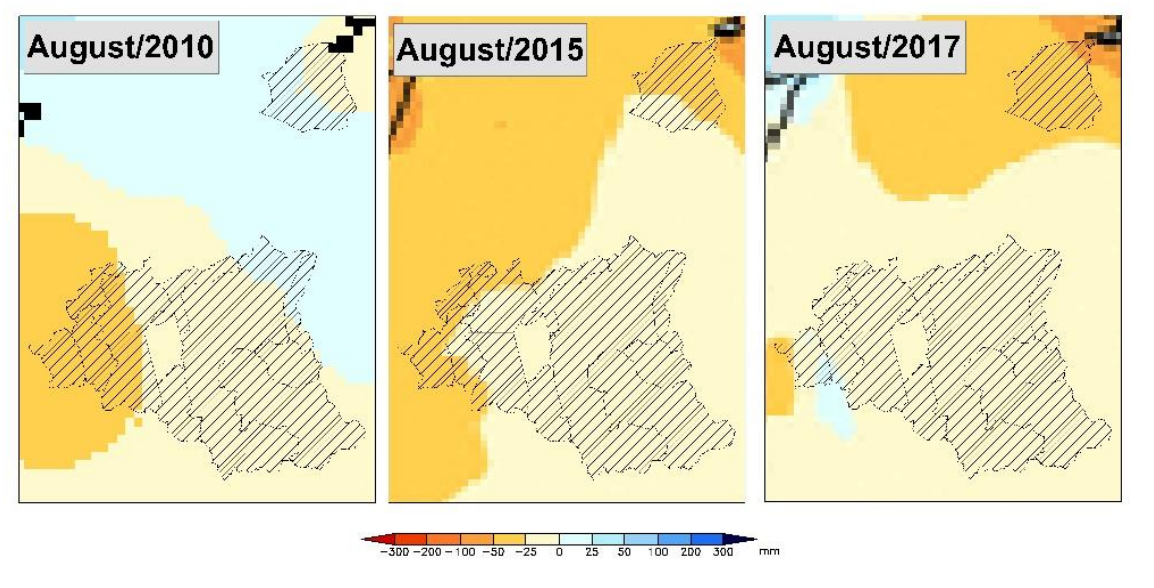

Figure 15 - Fire occurrence in the month of August of the years 2010, 2015 e 2017 (INPE, 2018b)
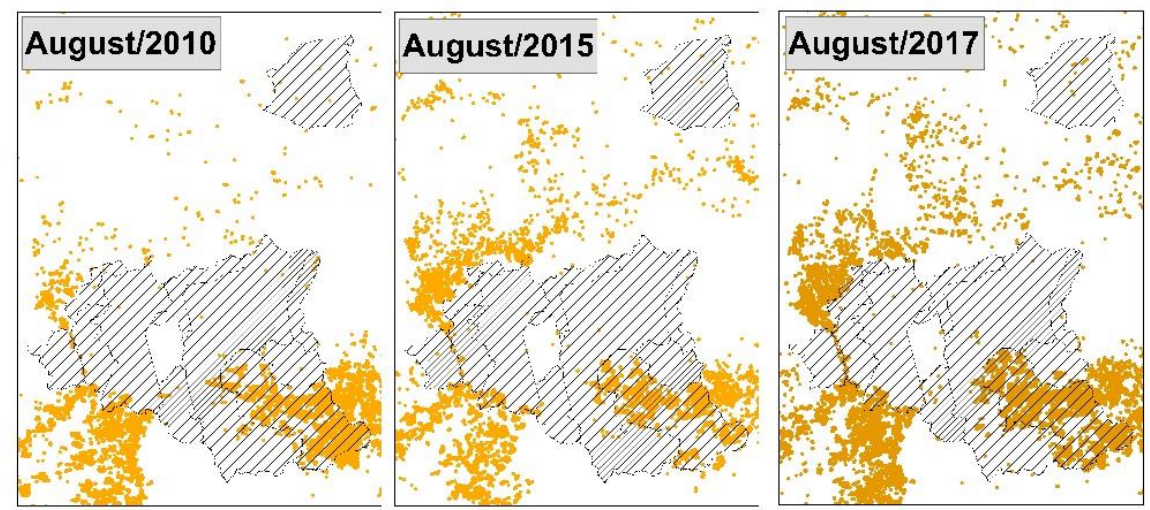
Until 2018 October, there were 570 mining processes registered in the National Department of Mineral Production (DNPM = Departamento Nacional de Produção Mineral) in the inner part or adjacent to the Terra do Meio Mosaic (Table 3). The main minerals explored are gold, cassiterite and platinum, which account respectively for $61 \%, 17 \%$ and $9 \%$ of the registered processes. Sonter et al. (2017) showed that deforestation in mining leases was three times higher than the average Amazon deforestation rate caused by the direct consequences of mining. Indirectly, this activity caused further deforestation that extends $70 \mathrm{~km}$ from the mining leases. The mining activity has indirect consequences for the establishment of its infrastructure, such as the opening of roads, urban expansion to accommodate the work force and other economic activities.

Table 3 - Mining processes in the interior and adjacent to Terra do Meio Mosaic (ANM, 2018)

Use

CU Name

Number of processes

$\%$ Processes

\begin{tabular}{lccc} 
& Serra do Pardo NP & 16 & $3 \%$ \\
Full & Terra do Meio ES & 44 & $8 \%$ \\
Protection & Jamanxim NP & 213 & $37 \%$ \\
\cline { 2 - 4 } & Total FPCU & 273 & $44 \%$ \\
\cline { 2 - 4 } & SF Iriri & 45 & $8 \%$ \\
Sustainable & Triunfo do Xingu EPA & 159 & $28 \%$ \\
Use & Altamira NF & 47 & $8 \%$ \\
& Verde para Sempre ER & 2 & $0 \%$ \\
& Riozinho do Anfrísio ER & 28 & $5 \%$ \\
Trairão NF & 40 & $3 \%$ \\
Rio Iriri ER & 15 & $2 \%$ \\
\hline Rio Xingu ER & 11 & $56 \%$ \\
\hline Total SUCU & 347 & \\
\hline
\end{tabular}


Hansen and DeFries (2007) point out three conditions in which a protected area becomes vulnerable to land use intensification: a) ecological characteristics of the protected area and the surrounding ecosystem; b) socio-economic characteristics of surrounding communities; and c) type and rates of conversion and intensification of the use. The CUs of the Terra do Meio Mosaic are located in a strategic and high priority region for conservation of the Amazonian socio-biodiversity, but it suffers from anthropization pressures in the large sites around it and even through the interior. The predominant economic activities in its surroundings are essentially detrimental to the forest ecosystem that the CUs protect; on the other hand, the presence of traditional communities in these units is a benefit for biodiversity conservation, since these populations are favored by the forest resources. The conversion of the forest to agropastoral and mining uses have different rates and intensities in the extension of the Mosaic and its impacts should be evaluated by the management of the CUs.

\section{CONCLUSIONS}

The CUs in the Terra do Meio Mosaic have been efficient in restraining deforestation, with exception of the Triunfo do Xingu EPA. However, the management of these units should contribute to the monitoring and inspection of activities that are not compatible with their category.

The National Plan of Protected Areas (Decree 5,758 of April 13, 2006) extends the concept of protected areas incorporating Indigenous Lands and lands occupied by remnants of the maroon communities. The ILs act as an important element of the CUs buffer zone, since they are effectively inhibiting deforestation in the Terra do Meio region.

The Management Plan is the instrument to guide the objectives of the categories foreseen in the SNUC. It is this document that will define the internal zoning of the unit and to establish guidelines for the decision making that contemplate the conservation of the socio-biodiversity and the landscape in the Terra do Meio Mosaic. Therefore, the federal and state agencies responsible for their management should not ignore their elaboration, which is a priority behavior in relation to other monitoring and inspection attempts. The shared management of Conservation Units Mosaics is a challenging action and must concern managers and the traditional people who live inside the protected areas. 
The level of restriction of the Ecological Station category reinforces the effectiveness of the protected area in repressing activities that are not compatible with this group of FPCUs. Therefore, it is understood that the Terra do Meio Ecological Station has the potential to fulfill its objective of preserving nature, even in an area inhabited by human populations. Although the SNUC establishes that the private areas within its boundaries are to be expropriated, it is worth considering that these communities, when stablished in their frontiers, contribute to the vigilance of the CUs.

Rather than representing spaces for biodiversity conservation, EPAs must follow an Environmental Zoning with guidance on permitted and restricted activities. The Triunfo do Xingu EPA is the protected area which has the lowest conservation strength. The EPA must promote territorial planning and its management must control the activities that are potential causes of environmental degradation. Therefore, although this category includes public and private territories, it is important that activities carried out in private territories do not harm the adjacent Full Protection CUs. Even in full interdiction of activities within the EPA (FARENA, 2007), properties must still fulfill its social function, according to the Constitutional Text written in 1988 (BRAZIL, 1988), incorporating the social and ecological functions to include environmental conservation and the conscious use of the natural resources to achieve both economic and socio-environmental benefits (IPAM, 2006).

Therefore, the Management Plan and the Environmental Zoning of EPA, or at least an emergency action plan, should consider indicators to regulate potentially pollutant activities or the use of natural resources. In these areas, the only regulatory instrument ends up being the Rural Environmental Register that defines spatially and quantitatively Legal Reserves and Permanent Preservation Areas. The increase in the rate of deforestation in Triunfo do Xingu EPA means a step backwards to achieve the goal defined in the National Policy on Climate Change (PNMC = Política Nacional de Mudanças Climáticas) (BRAZIL, 2009), which is $80 \%$ reduction by 2020 .

\section{ACKNOWLEDGMENTS}

This study was financed in part by the Coordenação de Aperfeiçoamento de Pessoal de Nível Superior - Brasil (CAPES) - Finance Code 001. 


\section{REFERENCES}

ALARCON DF, TORRES MG (2014) "Não tem essa lei no mundo, rapaz!" A Estação Ecológica da Terra do Meio e a resistência dos beiradeiros do alto rio Iriri. São Paulo: ISA Instituto Socioambiental; Altamira: Amora - Associação dos Moradores da Reserva Extrativista Riozinho do Anfrísio [Internet]. São Paulo: ISA - Instituto Socioambiental/ Altamira: Amora - Associação dos Moradores da Reserva Extrativista Riozinho do Anfrísio; 2014 [cited 2018 nov 01]. Available from: https://www.socioambiental.org/sites/blog.socioambiental.org/files/blog/pdfs/nao_tem_es sa_lei_no_mundo_ebook.pdf.

ANDERSEN LE, GRANGER CWJ, REIS EJ, WEINHOLD D, WUNDER S. The Dynamics of Deforestation and Economic Growth in the Brazilian Amazon. Cambridge: Cambridge University Press; 2002.

ANM - AGÊNCIA NACIONAL DE MINERAÇÃO [Internet]. Brasília: Ministério de Minas e Energia (BR) [cited 2018 dec 08]. SIGMINE: Sistema de Informações Geográficas da Mineração. Available from: http://www.anm.gov.br/assuntos/ao-minerador/sigmine.

BARBER CP, COCHRANE MA, SOUZA JR CM, LAURANCE WF. Roads, deforestation, and the mitigating effect of protected areas in the Amazon. Biol Conserv.2014;177:203-209.

BONAN G. Forests and climate change: forcings, feedbacks, and the climate benefits of forests. Science. 2008; 320(5882):1444-1449.

BRAGA ACR, MARTENSEN AC. Smallholders: Drivers or targets of Amazonian Deforestation? Hum Geogr. 2017; 10(1):67-69.

BRANCALION PHS, GARCIA LC, LOYOLA R, RODRIGUES RR, PILLAR VD, LEWINSOHN TM. A critical analysis of the Native Vegetation Protection Law of Brazil (2012): updates and ongoing initiatives. Nat Conservacao. 2016; 4S:1-15.

BRAZIL (1988) Constitution of the Federative Republic of Brazil: enacted on October 5, 1988. Brasília (Brazil): Presidência da República - Casa Civil; 1998.

BRAZIL. Law 9,985 of July 18th, 2000. Regulates art. 225, § 1, items I, II, III and VII of the Federal Constitution, establishes the National System of Nature Conservation Units and other measures. Brasília (Brazil): Presidência da República - Casa Civil; 2000.

BRAZIL. Decree 4,340 of August 22nd, 2002. Regulates articles of Law No. 9,985, of July 18th, 2000, which provides for the National System of Nature Conservation Units (SNUC) and other measures. Brasília (Brazil): Presidência da República - Casa Civil; 2002.

BRAZIL. Decree 5,051 of April 19th, 2004. Promulgates Convention 169 of the International Labor Organization - ILO on Indigenous and Tribal Peoples. Brasília (Brazil): Presidência da República - Casa Civil; 2004.

BRAZIL. Decree 5.758 of April 13th, 2006. Establishes the National Strategic Plan for Protected Areas - NSPPA, its principles, guidelines, objectives and strategies, and other measures. Brasília (Brazil): Presidência da República - Casa Civil; 2006. 
BRAZIL. Law 12,187 of December 29th, 2009. Establishes the National Policy on Climate Change and makes other provisions. Brasília (Brazil): Presidência da República - Casa Civil; 2009.

BRAZIL. Law no. 12.651, of May 25th, 2012. Provides for the protection of native vegetation; amends Laws 6,938 of August 31th, 1981, 9,393 of December 19th, 1996 and 11,428 of December 22nd, 2006; revokes Laws Nos. 4,771, September 15th, 1965 and 7,754, April 14th, 1989, and Provisional Measure No. 2,166-67 of August 24th, 2001; and makes other arrangements. Brasília (Brazil): Presidência da República - Casa Civil; 2012.

BRITO DMC, BRITO BLR, SIQUEIRA GV. Proteção da natureza e conflitos socioambientais. Brasil. Plan. Amaz. 2014; 6:171-187.

CPTEC - CENTRO DE PREVISÃO DE TEMPO E ESTUDOS CLIMÁTICOS [Internet]. Brasília: Ministério da Ciência, Tecnologia, Inovação e Comunicação (BR) [cited 2018 dec 08]. Monitoramento Brasil. Available from: http://clima1.cptec.inpe.br/monitoramentobrasil/pt.

FARENA DVM. Aspectos polêmicos acerca da criação e implantação de unidades de Conservação. Bol. Cient. / Esc. Super. Minist. Público União. 2007;24-25:123-150.

FEARNSIDE PM. Deforestation in Brazilian Amazonia: the effect of population and land tenure. Ambio. 1993; 22(3):537-545.

FEARNSIDE PM. Desmatamento na Amazônia brasileira: História, índices e consequências. Megadiversidade. 2005; 1(4):113-123.

FEARNSIDE PM. The roles and movements of actors in the deforestation of Brazilian Amazonia. Ecol Soc. 2008; 13(1): article 23.

FEARNSIDE PM. Deforestation in Brazilian Amazonia. In: Wohl E, editor. New York: Oxford University Press; 2017. p 1-33.

FUNAI - FUNDAÇÃO NACIONAL DO ÍNDIO [Internet] Brasília: Ministério da Mulher, da Família e dos Direitos Humanos (BR) [cited 2018 sep 15]. Available from: http://www.funai.gov.br/index.php/shape.

HANSEN AJ, DEFRIES R. Ecological mechanisms linking protected areas to surrounding lands. 2007; Ecol Appl 17(4):974-988.

IBGE - INSTITUTO BRASILEIRO DE GEOGRAFIA E ESTATÍSTICA [Internet]. Brasília: Ministério da Economia (BR) [cited 2018 oct 20]. Pesquisa da Pecuária Municipal. Available from: https://sidra.ibge.gov.br/tabela/3939\#resultado.

ICMBio - INSTITUTO CHICO MENDES DE CONSERVAÇÃO DA BIODIVERSIDADE. Brasília: Ministério do Meio Ambiente; 2015 [cited 2018 oct 01]. Plano de Manejo da Estação Ecológica da Terra do Meio. Avaolable from: http://www.icmbio.gov.br/portal/unidadesdeconservacao/biomasbrasileiros/amazonia/unidades-de-conservacao-amazonia/1909-esec-da-terra-do-meio.

INCRA - INSTITUTO NACIONAL DE COLONIZAÇÃO E REFORMA AGRÁRIA [Internet]. Brasília: Ministério do Desenvolvimento Agrário (BR) [cited 2018 oct 01]. Acervo Fundiário. Available from: http://acervofundiario.incra.gov.br. 
INCRA - INSTITUTO NACIONAL DE COLONIZAÇÃO E REFORMA AGRÁRIA. [Internet]. Brasília: Ministério do Desenvolvimento Agrário (BR) [cited 2019 feb 27]. Sistema Nacional de Cadastro Rural - Índices Básicos de 2013. Available from: http://www.incra.gov.br/sites/default/files/uploads/estrutura-fundiaria/regularizacaofundiaria/indices-cadastrais/indices_basicos_2013_por_municipio.pdf.

INPE - INSTITUTO NACIONAL DE PESQUISAS ESPACIAIS [Internet]. Brasília: Ministério da Ciência, Tecnologia, Inovação e Comunicação (BR) [cited 2018a sep 15]. PRODES Monitoramento da Floresta Amazônica Brasileira por Satélite. Available from: http://www.dpi.inpe.br/prodesdigital/prodes.php.

INPE - INSTITUTO NACIONAL DE PESQUISAS ESPACIAIS [Internet]. Brasília: Ministério da Ciência, Tecnologia, Inovação e Comunicação (BR) [cited 2018b sep 15]. Banco de Dados de Queimadas. http://www.inpe.br/queimadas/bdqueimadas.

IPAM - INSTITUTO DE PESQUISA AMBIENTAL DA AMAZÔNIA. A grilagem de terras pública na Amazônia Brasileira. Brasília: MMA; 2006.

ISA - Instituto Socioambiental [Internet]. Brasília: ISA (BR) [cited 2018 apr 16]. Unidades de Conservação. Available from: https://www.socioambiental.org/.

MAPBIOMAS [Internet]. Brasília: Rede MapBiomas [cited 2018 sep 15]. Brazilian Annual Land Use and Land Cover Mapping Project. Available from: http://mapbiomas.org.

MMA - MINISTÉRIO DO MEIO AMBIENTE [Internet]. Brasília: Ministério do Meio Ambiente (BR) [cited 2018 nov 05]. Action Plan for the Prevention of Deforestation Control in the Amazon. Available from: http://www.mma.gov.br/informma/item/616preven\%C3\%A7\%C3\%A3o-e-controle-do-desmatamento-na-amaz\%C3\%B4nia.html.

NEPSTAD D, SCHWARTZMAN S, BAMBERGER B, SANTILLI M, RAY B, SCHLESINGER P, et al. Inhibition of Amazon Deforestation and Fire by Parks and Indigenous Lands. Conserv Biol. 2006; 20(1):65-73.

NOGUEIRA EM, YANAI AM, VASCONCELOS SS, GRAÇA PMLA, FEARNSIDE PM. Carbon stocks and losses to deforestation in protected areas in Brazilian Amazonia. Reg Environ Change. 2018; 8(1)261-270.

OLIVEIRA JAP. Property rights, land conflicts and deforestation in the Eastern Amazon. For Policy Econ. 2008; 10(5):303-315.

OLIVEIRA LJC, COSTA MH, SOARES-FILHO BS, COE MT Large-scale expansion of agriculture in Amazonia may be a no-win scenario. Environ Res Lett. 2013; 8, 024021.

RASKER R, HANSEN AJ. Natural amenities and population growth in the Greater Yellowstone region. Hum Ecol Ver. 2000; 7:30-40.

SETZER A, JESUS SC, MORELLI F, MAURANO, LE. A case of illegal clearing in Amazonia antecipated by the detection of fires and forest degradation. In: Proceedings of the $10^{\text {th }}$ Seminário de Atualização em Sensoriamento Remoto e Sistemas de Informações Geográficas Aplicados à Engenharia Florestal; 2012 oct 15-18; Curitiba-Brazil. 
SICAR - SISTEMA NACIONAL DE CADASTRO AMBIENTAL RURAL. Brasília: Ministério da Agricultura, Pecuária e Abastecimento Cadastro Ambiental Rural (BR) [cited 2019 feb 27]. Available from: http://www.car.gov.br/publico/imoveis/index.

STRAND J, SOARES-FILHO B, COSTA MH, OLIVEIRA U, RIBEIRO SC, PIRES GF, et al. Spatially explicit valuation of the Brazilian Amazon Forest's Ecosystem Services. Nat Sustain., 2018; 1: 657-664.

SONTER LJ, HERRERA D, BARRETT DJ, GALFORD GL, MORAN CJ, SOARES-FILHO, BS. Mining drives extensive deforestation in the Brazilian Amazon. Nat Commun. 2017; 8(1013):1-7.

VERBURG R, RODRIGUES FILHO S, LINDOSO D, DEBORTOLI N, LITRE G, BURSZTYN M. The impact of commodity price and conservation policy scenarios on deforestation and agricultural land use in a frontier area within the Amazon. Land Use Policy. 2014; 37:1426.

VILLAS-BÔAS A, SANCHES RA, SCARAMUZZA CAM. Estudos preliminares e formulação de uma proposta técnica para a implantação de um mosaico de Unidades de Conservação no Médio Xingu. São Paulo: Instituto Socioambiental; 2003.

YOUNG CEF, MEDEIROSR, editors. Quanto vale o verde: a importância econômica das unidades de conservação brasileiras. Rio de Janeiro: Conservação Internacional; 2018. 